\title{
Predictors of a variceal source among patients presenting with upper gastrointestinal bleeding
}

\author{
Ahmad Alharbi MBBS FRCPC 1 , Majid Almadi MBBS FRCPC ${ }^{1}$, Alan Barkun MD CM MSc FRCPC ${ }^{1,2}$, \\ Myriam Martel $\mathrm{BSc}^{1}$; the REASON Investigators*
}

\begin{abstract}
A Alharbi, M Almadi, A Barkun, M Martel; the REASON investigators. Predictors of a variceal source among patients presenting with upper gastrointestinal bleeding. Can J Gastroenterol 2012;26(4):187-192.
\end{abstract}

BACKGROUND: Patients with upper gastrointestinal bleeding (UGIB) require an early, tailored approach best guided by knowledge of the bleeding lesion, especially a variceal versus a nonvariceal source. OBJECTIVE: To identify, by investigating a large national registry, variables that would be predictive of a variceal origin of UGIB using clinical parameters before endoscopic evaluation.

METHODS: A retrospective study was conducted in 21 Canadian hospitals during the period from January 2004 until the end of May 2005. Consecutive charts for hospitalized patients with a primary or secondary discharge diagnosis of UGIB were reviewed. Data regarding demographics, including historical, physical examination, initial laboratory investigations, endoscopic and pharmacological therapies administered, as well as clinical outcomes, were collected. Multivariable logistic regression modelling was performed to identify clinical predictors of a variceal source of bleeding.

RESULTS: The patient population included 2020 patients (mean [ \pm SD] age $66.3 \pm 16.4$ years; $38.4 \%$ female). Overall, 215 (10.6\%) were found to be bleeding from upper gastrointestinal varices. Among 26 patient characteristics, variables predicting a variceal source of bleeding included history of liver disease (OR 6.36 [95\% CI 3.59 to 11.3]), excessive alcohol use (OR 2.28 [95\% CI 1.37 to 3.77]), hematemesis (OR 2.65 [95\% CI 1.61 to 4.36]), hematochezia (OR 3.02 [95\% CI 1.46 to 6.22$]$ ) and stigmata of chronic liver disease (OR 2.49 [95\% CI 1.46 to 4.25$]$ ). Patients treated with antithrombotic therapy were more likely to experience other causes of hemorrhage (OR 0.44 [95\% CI 0.35 to 0.78$]$ ).

CONCLUSION: Presenting historical and physical examination data, and initial laboratory tests carry significant predictive ability in discriminating variceal versus nonvariceal sources of bleeding.

Key Words: Chronic liver disease; Esophageal varices; Gastrointestinal hemorrhages; Hematemesis; Melena

$\mathrm{V}$ ariceal bleeding is associated with a high mortality rate. Over the past few decades, mortality has decreased (1) due to improvements in endoscopic interventions, antibiotic use and pharmacological therapies, with a drop in the six-week mortality rate from earlier rates of $42 \%(2)$ to approximately $16 \%(1,3)$. Nonetheless, the recurrence rate remains high at $13 \%$ to $29 \%(1,3)$. Early recognition of variceal bleeding is crucial because the initial management of patients with a variceal source is different from that of a nonvariceal source (4-7).

The ability of bedside variables to predict the source of upper gastrointestinal bleeding (UGIB) remains controversial and has been poorly assessed in only a very few recent studies yielding predictors that have yet to be formally assessed in a North American population (8).

\section{Les variables prédictives de saignements œsogastroduodénaux d'origine variqueuse chez les patients}

HISTORIQUE : Les patients présentant des saignements œsogastroduodénaux (SOGD) ont besoin d'une approche précoce et personnalisée orientée par la connaissance de la lésion hémorragique, notamment son origine variqueuse ou non variqueuse.

OBJECTIF : En examinant un grand registre national, déterminer les variables prédictives de SOGD d'origine variqueuse au moyen de paramètres cliniques relevés avant l'évaluation endoscopique.

MÉTHODOLOGIE : Les chercheurs ont procédé à une analyse prospective dans 21 hôpitaux canadiens entre janvier 2004 et la fin de mai 2005. Ils ont analysé les dossiers consécutifs de patients hospitalisés dont le diagnostic primaire ou secondaire au congé en était un de SOGD. Ils ont colligé des données au sujet des facteurs démographiques, y compris les antécédents, l'examen physique, les premiers examens de laboratoire, les traitements endoscopiques et pharmacologiques administrés et les issues cliniques. Ils ont effectué une modélisation de la régression logistique multivariable pour déterminer les variables prédictives cliniques de saignements d'origine variqueuse.

RÉSULTATS : La population à l'étude se composait de 2020 patients (âge moyen [ $\pm E ́ T]$ de 66,3 $\pm 16,4$ ans; $38,4 \%$ de femmes). Dans l'ensemble, $215(10,6 \%)$ avaient des saignements causés par des varices œsogastroduodénales. Parmi 26 caractéristiques des patients, les variables prédictives de saignements d'origine variqueuse incluaient des antécédents de maladie hépatique (RRR 6,36 [95 \% IC 3,59 à $11,3]$ ), de consommation excessive d'alcool (RRR 2,28 [95 \% IC 1,37 à 3,77]), d'hématémèse (RRR 2,65 [95 \% IC 1,61 à 4,36]), d'hématochézie (RRR 3,02 [95 \% IC1,46 à 6,22]) et de stigmates de maladie hépatique chronique (RRR 2,49 [95 \% IC 1,46 à 4,25]). Les patients traités aux antithrombotiques étaient plus susceptibles d'avoir des saignements attribuables à d'autres causes (RRR 0,44 [95 \% IC 0,35 à 0,78]).

CONCLUSION : Les antécédents, les données de l'examen physique et les premiers tests de laboratoire s'associent à une importante capacité prédictive de distinguer des saignements d'origine variqueuse de ceux d'origine non variqueuse.

Using clinical parameters and laboratory investigations obtained from a large registry database, the current study attempted to identify variables predictive of UGIB from a variceal source before endoscopic evaluation.

\section{Patient population}

\section{METHODS}

Patients at least 18 years of age who presented with nonvariceal or variceal UGIB between January 2004 and May 31, 2005, up to a total of 2000 admitted patients, were enrolled in the national REgistry of patients undergoing endoscopic and/or Acid Suppression therapy and Outcomes analysis for upper gastrointestinal bleediNg (REASON). A

\footnotetext{
${ }^{1}$ Division of Gastroenterology; 2Division of Clinical Epidemiology, The McGill University Health Centre, Montreal General Hospital, McGill University,

Montreal, Quebec. "Members of the the national REgistry of patients undergoing endoscopic and/or Acid Suppression therapy and Outcomes analysis for upper gastrointestinal bleediNg (REASON) are listed in Appendix 1

Correspondence: Dr Alan Barkun, Division of Gastroenterology, The McGill University Health Center, Montreal General Hospital site,

1650 Cedar Avenue, room D7-346, Montreal, Quebec H3G 1A4. Telephone 514-934-8309, fax 514-834-8531, e-mail alan.barkun@muhc.mcgill.ca Received for publication May 13, 2011. Accepted July 9, 2011
} 
TABLE 1

Demographic and baseline characteristics of patients with nonvariceal upper gastrointestinal bleeding (UGIB) or variceal bleeding

\begin{tabular}{|c|c|c|c|c|}
\hline \multirow[b]{2}{*}{ Demographics and baseline characteristics } & \multirow[b]{2}{*}{ All patients $(n=2020)$} & \multicolumn{2}{|c|}{ Bleed } & \multirow[b]{2}{*}{$\mathbf{P}$} \\
\hline & & Variceal $(n=215)$ & Nonvariceal $(n=1805)$ & \\
\hline Age, years, mean \pm SD & $66.3 \pm 16.4$ & $58.0 \pm 12.3$ & $67.2 \pm 16.6$ & $<0.0001$ \\
\hline \multicolumn{5}{|l|}{ Sex } \\
\hline Female & 775 (38.4); 36.2-40.5 & $64(29.8) ; 23.6-35.9$ & $711(39.4) ; 37.1-41.7$ & 0.0061 \\
\hline Male & 1245 (61.6); 59.5-63.8 & 151 (70.2); 64.4-76.4 & $1094(60.6) ; 58.3-62.9$ & \\
\hline \multicolumn{5}{|l|}{ Documented history of the following: } \\
\hline Nonvariceal UGIB & 302 (15.0); 16.5-13.4 & $22(10.2) ; 6.2-14.3$ & $280(15.5) ; 13.8-17.2$ & 0.0401 \\
\hline Variceal UGIB & $136(6.7) ; 5.6-7.8$ & 91 (42.3); 35.7-49.0 & 45 (2.5); 1.8-3.2 & $<0.0001$ \\
\hline Peptic ulcer disease & 390 (19.3); 17.6-21.0 & $31(14.4) ; 9.7-19.2$ & 359 (19.9); 18.1-21.7 & 0.0547 \\
\hline Peptic ulcer bleeding & $169(8.4) ; 7.2-9.6$ & $15(7.0) ; 3.5-10.4$ & $154(8.5) ; 7.2-9.8$ & 0.4363 \\
\hline Liver disease & 328 (16.2); 14.6-17.9 & 166 (77.2); 71.6-82.9 & $162(9.0) ; 7.7-10.3$ & $<0.0001$ \\
\hline Malignancies & 376 (18.6); 16.9-20.3 & 35 (16.3); 11.3-21.3 & 341 (18.9); 17.1-20.7 & 0.3521 \\
\hline Bleeding disorders & $85(4.2) ; 3.3-5.1$ & $24(11.2) ; 6.9-15.4$ & $61(3.4) ; 2.6-4.2$ & $<0.0001$ \\
\hline Cardiac failure & 319 (15.8); 14.2-17.4 & $14(6.5) ; 3.2-9.8$ & 305 (16.9); 15.2-18.6 & $<0.0001$ \\
\hline Excessive alcohol use & 425 (21.0); 19.3-22.8 & 113 (52.6); 45.8-59.3 & 312 (17.3); 15.5-19.0 & $<0.0001$ \\
\hline Abdominal surgery & 665 (32.9); 30.9-35.0 & $52(24.2) ; 18.4-30.0$ & $613(34.0) ; 31.8-36.2$ & 0.0039 \\
\hline \multicolumn{5}{|l|}{ Helicobacter pylori status at initial bleeding episode } \\
\hline Positive & $66(3.3) ; 2.5-4.0$ & $3(1.4) ; 0.0-3.0$ & $63(3.5) ; 2.6-4.3$ & 0.1024 \\
\hline Negative & 131 (6.5); 5.4-7.6 & $10(4.7) ; 1.8-7.5$ & $121(6.7) ; 5.6-7.9$ & 0.248 \\
\hline Not documented & 1823 (90.3); 89.0-91.5 & 202 (94.0); 90.7-97.2 & 1621 (89.8); 88.4-91.2 & 0.0527 \\
\hline Comorbidities at time of initial bleeding, mean \pm SD & $2.6 \pm 1.8$ & $2.5 \pm 1.5$ & $2.6 \pm 1.8$ & 0.9929 \\
\hline \multicolumn{5}{|l|}{ Use of the following: } \\
\hline Selective serotonin reuptake inhibitors & $80(5.2) ; 4.1-6.3$ & $6(4.9) ; 1.0-8.8$ & $74(5.2) ; 4.1-6.4$ & 0.8885 \\
\hline Antithrombotic agents & 806 (52.3); 49.8-54.8 & $26(21.3) ; 13.9-28.7$ & 780 (54.9); 52.3-57.5 & $<0.0001$ \\
\hline Proton pump inhibitors & $373(24.2) ; 22.1-26.3$ & 56 (45.9); 36.9-54.9 & 317 (22.3); 20.2-24.5 & $<0.0001$ \\
\hline Acetaminophen & 360 (23.4); 21.2-25.5 & 27 (22.1); 14.7-29.6 & 333 (23.5); 21.2-25.7 & 0.7409 \\
\hline Bisphosphonates & $85(5.5) ; 4.4-6.7$ & $3(2.5) ; 0.0-5.3$ & $82(5.8) ; 4.6-7.0$ & 0.1236 \\
\hline Calcium channel blockers & 228 (14.8); 13.0-16.6 & $7(5.7) ; 1.6-9.9$ & $221(15.6) ; 13.7-17.5$ & 0.0033 \\
\hline Steroids & $113(7.3) ; 6.0-8.6$ & $4(3.3) ; 0.1-6.5$ & $109(7.7) ; 6.3-9.1$ & 0.0737 \\
\hline Nonsteroidal anti-inflammatory drugs & 480 (31.1); 28.8-33.4 & 28 (23.0); 15.4-30.5 & 452 (31.8); 29.4-34.3 & 0.0421 \\
\hline $\mathrm{H}_{2}$ receptor antagonists & $164(10.6) ; 9.1-12.2$ & $7(5.7) ; 1.6-9.9$ & 157 (11.1); 9.4-12.7 & 0.0675 \\
\hline
\end{tabular}

Data presented as $n$ (\%); 95\% Cl unless otherwise indicated. Percentages shown are for the percentage of patients in the nonvariceal population (total $n=1805$ ) or in the variceal population (total $n=215)$ or for the total population $(n=2020)$

total of 21 hospitals across Canada participated. Patients initially assessed for the present episode of bleeding at an institution not part of the study and subsequently transferred to a participating site for further management, as well as patients presenting with UGIB to the emergency room and who were not admitted to hospital, were excluded from the study. Patients were identified through the diagnosis documented in hospital records using the International Classification of Diseases, 9th or 10th Revision (ICD-9 or ICD-10) codes. All patients who had a primary or secondary coded discharge diagnosis of UGIB were screened for eligibility. Successive patients fulfilling selection criteria were entered.

\section{Study design}

The charts of all hospitalized patients were retrospectively reviewed by a local, trained research nurse. Once a patient was identified as a potential candidate from medical record lists, the hospital chart was obtained for further review to ensure the patient met all eligibility criteria. If so, the patient was assigned an enrollment code, and information from the medical chart was entered into an electronic database by a trained research nurse. An Internet-based case report form, specifically designed for the present study with standardized definitions for variables, was used in addition to a centralized data validation process previously described in the literature (9); $10 \%$ of all records were also audited by an independent study nurse. The entered data were reviewed centrally, with validation performed by an independent reviewer with medical knowledge who audited the progress of care of a given patient according to the entered data and decided on whether the recorded information was internally consistent. Ranges for each variable were required to fall within a range of preset, biologically plausible values.

\section{Recorded information}

Demographic data, historical information, endoscopic and pharmacological therapies administered, as well as clinical outcome data were collected.

A variable - 'stigmata of chronic liver disease' - was created to simplify the analysis while maintaining clinical relevance. This variable was a composite of the presence of any of the following for a given patient: hepatomegaly, splenomegaly, peripheral edema, jaundice, hepatic encephalopathy and ascites. The Model for End-stage Liver Disease (MELD) score was calculated with the available data (10). To ensure patient confidentiality, no personal identification information or other personal identifiers, such as address or hospital identification number, were recorded.

\section{Statistical analysis}

Descriptive variables are presented as percentages or mean \pm SD. Inferential univariable analysis was only performed on clinically relevant variables determined a priori using the $\chi^{2}$ test for categorical variables or a Wilcoxon nonparametric test for continuous variables. Multivariable analyses were performed using logistic regression modelling, with associated ORs. All analyses were performed using SAS 
software version 9.2 (SAS Institute, USA). A statistical significance threshold of $\mathrm{P}=0.05$ was adopted. No attempt at imputation was performed for missing data.

\section{RESULTS}

Patient population

Demographics and historical information: A total of 2020 patients were included in the REASON registry. Overall, 215 (10.6\%) patients were found to be bleeding from upper gastrointestinal varices. Varices were esophageal in $90.7 \%$ and gastric in $28.9 \%$ of patients.

The basic demographic and medical history information of all patients presenting with UGIB and, more specifically, among those with variceal bleeding are presented in Table 1 . In the latter group, the mean age was $58.0 \pm 12.3$ years, including 64 (29.8\%) females. A history of variceal UGIB was noted in $91(42.3 \%)$ patients, liver disease in $166(77.2 \%)$ and excessive alcohol use in $113(52.6 \%)$. The mean number of comorbidities was 2.5 (range zero to eight) at the time of initial bleeding. Presenting symptoms are shown in Table 2. For patients with variceal UGIB, the number of patients who presented with a history of melena was $134(62.3 \%)$, hematemesis $116(54.0 \%)$ and syncope $15(7.0 \%)$, and the number of patients with an American Society of Anesthesiologists (ASA) score of IV or V was 74 (34.4\%).

\section{Study population}

Physical examination findings: Relevant physical examination findings for the overall population and, more specifically, for the patients with variceal bleeding, are summarized in Table 2. At presentation, the number of patients who had a variceal source of bleeding and initial hemodynamic instability was $67(31.2 \%)$, splenomegaly $38(17.7 \%)$, mild to moderate ascites $61(28.4 \%)$ and severe ascites $22(10.2 \%)$; jaundice was found in 47 (21.9\%).

In the same group, the number of patients who had bright red blood per rectum was $14(6.5 \%)$ and melena 43 (20.0\%). A nasogastric intubation (NGT) aspirate demonstrated bright red blood in $16(7.4 \%)$ patients and coffee ground material in $10(4.7 \%)$. The group of patients in whom information about NGT was recorded totalled 448. Of these, 123 (23.3\%) had bright red blood per NGT, $172(38.4 \%)$ coffee-ground material, 18 (4.2\%) bile and 135 (25.9\%) had no findings.

Laboratory data: Relevant initial laboratory data for the overall population, and more specifically for the patients with variceal bleeding, are presented in Table 3. In the latter group, the mean hemoglobin level was $93.8 \pm 23.2 \mathrm{~g} / \mathrm{L}$, platelet count $143.5 \pm 87.8 \times 10^{9} / \mathrm{L}$, blood urea nitrogen $10.9 \pm 8.4 \mathrm{mmol} / \mathrm{L}$, total bilirubin $44 \pm 54.6 \mu \mathrm{mol} / \mathrm{L}$, serum albumin $27.1 \pm 6.72 \mathrm{~g} / \mathrm{L}$, creatinine $108.8 \pm 104.7 \mu \mathrm{mol} / \mathrm{L}$.

The MELD score among patients with variceal bleeding averaged $11.1 \pm 8.4$ (range six to 40 points). In the nonvariceal group, the mean MELD score was $6.4 \pm 7.9$.

\section{Outcome data}

Among patients with variceal bleeding, eight (3.7\%) underwent a transhepatic portosystemic shunt procedure, one $(0.5 \%)$ underwent shunt surgery and another $(0.5 \%)$ underwent liver transplantation. Twenty-five $(11.6 \%)$ patients developed new or worsening encephalopathy.

The 30-day mortality rate for patients with nonvariceal bleeding was $9.4 \%$, while the rate for patients with variceal bleeding was $14.4 \%$.

\section{Univariable analysis}

Descriptive averages and proportions among patients with variceal versus nonvariceal bleeding are also presented in Tables 1 and 2 . Among the 26 clinically relevant predictors, significant differences in univariable analysis for patients bleeding from varices versus other causes, respectively, included age $(58.0 \pm 12.3$ versus $672 \pm 6.6$ years $)$, female sex $(29.8 \%$ versus $39.4 \%)$, history of previous nonvariceal UGIB ( $10.2 \%$ versus $15.5 \%)$, liver disease ( $77.0 \%$ versus $9.0 \%$ ), bleeding disorders (11.2\% versus $3.4 \%$ ), excessive alcohol intake $(52.6 \%$ versus $17.3 \%$ ), syncope (7.0\% versus $10.6 \%$ ), findings of coffee-ground material in the NGT aspirate (4.7\% versus $9.0 \%$ ), the presence of one or more stigmata of chronic liver disease ( $13 \%$ to $28 \%$ versus $1.9 \%$ to $4.7 \%)$, hemoglobin level $(93.8 \pm 23.2 \mathrm{~g} / \mathrm{L}$ versus $98.5 \pm 28.2 \mathrm{~g} / \mathrm{L})$, platelet count $\left(143.5 \pm 87.8 \times 10^{9} / \mathrm{L}\right.$ versus $\left.261.6 \pm 123.8 \times 10^{9} / \mathrm{L}\right)$, blood urea nitrogen $(10.9 \pm 8.4 \mathrm{mmol} / \mathrm{L}$ versus $13.8 \pm 10.3 \mathrm{mmol} / \mathrm{L})$, as well as elevated liver enzyme tests.

\section{Multivariable analysis}

Significant independent predictors associated with an increased likelihood of bleeding from a variceal source on multivariable analysis included: history of liver disease OR 6.36 (95\% CI 3.59 to 11.3); excessive alcohol use OR 2.28 (95\% CI 1.37 to 3.77); hematemesis OR 2.65 (95\% CI 1.61 to 4.36); hematochezia OR 3.02 (95\% CI 1.46 to 6.22); and stigmata of liver disease OR 2.49 (95\% CI 1.46 to 4.25$)$. In contrast, the use of antithrombotics OR 0.44 (95\% CI 0.35 to 0.78 ) predicted a nonvariceal cause of bleeding (Table 4).

The multivariable model that was used demonstrated adequate discrimination, with a C statistic of 0.91 .

\section{DISCUSSION}

UGIB is stratified into variceal and nonvariceal causes because such differentiation bears important clinical information when deciding on the most efficient and cost-effective subsequent approach based on published guidelines $(11,12)$. Differences in management include the suggested optimal duration until endoscopy ( $12 \mathrm{~h}$ versus later), the judicious use of resuscitation fluids and target hemoglobin level (80 g/L versus greater) $(13,14)$.

Bedside predictors of variceal UGIB have not been well studied. A recent literature search yielded only one study from Thailand assessing this issue (8). The predictive model reached a very high negative predictive value of $97 \%$ using an UGIB etiology score that included previous diagnosis of cirrhosis or the presence of signs of chronic liver disease, red vomitus and a red NGT aspirate. Factors limiting the universal applicability of these results include the small numbers of patients with variceal UGIB causes (47 in the initial cohort and 46 in the validation cohort) and the single-centre setting. The conclusions are, however, strengthened by validation of their initial findings in an independent population. These results may not be completely applicable to a North American population given differences in genetic backgrounds, causes of portal hypertension or cirrhosis.

Our study broadly represents patients from numerous centres that use a national Canadian database enrolling a large number of patients. Additional methodological strengths were the data quality procedures, such as an Internet-based case report form with standardized definitions for all variables and subsequent validation of $10 \%$ of all entered data by two independent nurses in addition to a centralized data validation process. Extensive pre-endoscopy information was collected for patients involved in the present study across multiple domains including presenting history, physical examination findings and laboratory data.

The present study demonstrated that patients with a variceal source of UGIB compared with nonvariceal causes were younger, more often men, and with risk factors that included a history of liver disease or bleeding disorder, excessive alcohol use, hematochezia, hematemesis, bright red blood on NGT aspiration, stigmata of chronic liver disease, lower serum albumin, lower platelet counts and more frequent abnormality in liver enzyme levels. On the other hand, patients with nonvariceal UGIB were more likely to have a history of abdominal surgery, had increased exposure to antithrombotics, calcium channel blockers or nonsteroidal anti-inflammatory drugs, and were less likely to have a high ASA score. Using multivariable logistic regression analysis, the only remaining significant independent predictors of a variceal source of bleeding included a documented history of liver disease (OR 6.36 [95\% CI 3.59 to 11.3]), excess alcohol use (OR 2.28 [95\% CI 1.37 to 3.77]), and the absence of use of antithrombotics (OR 0.44 [95\% CI [0.35 to 0.78]) as well as a clinical 
TABLE 2

Baseline physical examination and clinical findings at initial bleeding event for patients with either nonvariceal upper gastrointestinal bleeding or variceal bleeding

\begin{tabular}{|c|c|c|c|c|}
\hline \multirow[b]{2}{*}{ Symptoms on initial presentation with bleeding } & \multirow[b]{2}{*}{ All patients $(n=2020)$} & \multicolumn{2}{|c|}{ Bleed } & \multirow[b]{2}{*}{$\mathbf{P}$} \\
\hline & & Variceal $(n=215)$ & Nonvariceal (n=1805) & \\
\hline Melena & 1243 (61.5); 59.4-63.7 & $134(62.3) ; 55.8-68.9$ & 1109 (61.4); 59.2-63.7 & 0.8009 \\
\hline Hematochezia & $166(8.2) ; 7.0-9.4$ & 30 (14.); 9.3-18.6 & $136(7.5) ; 6.3-8.8$ & 0.0012 \\
\hline Hematemesis & $654(32.4) ; 30.3-34.4$ & $116(54.0) ; 47.2-60.7$ & 538 (29.8); 27.7-31.9 & $<0.0001$ \\
\hline Syncope & $206(10.2) ; 8.9-11.5$ & 15 (7.0); 3.5-10.4 & $191(10.6) ; 9.2-12.0$ & 0.0987 \\
\hline \multicolumn{5}{|l|}{ ASA at the time of initial presentation } \\
\hline 1 & 280 (13.9); 12.4-15.4 & 7 (3.3); 0.9-5.7 & 273 (15.1); 13.5-16.8 & $<0.0001$ \\
\hline II & 563 (27.9); 25.9-29.8 & 49 (22.8); 17.1-28.4 & 514 (28.5), 26.4-30.6 & 0.0788 \\
\hline III & $776(38.4) ; 36.3-40.5$ & 85 (39.5), 33.0-46.1 & 691 (38.3); 36.0-40.5 & 0.7212 \\
\hline IV & 389 (19.3); 17.5-21.0 & $73(34.0) ; 27.6-40.3$ & 316 (17.5); 15.8-19.3 & $<0.0001$ \\
\hline V & $12(0.6) ; 0.2-0.9$ & 1 (0.5); 0.0-1.4) & $11(0.6) ; 0.3-1.0$ & 0.7947 \\
\hline \multicolumn{5}{|l|}{ Physical examination findings } \\
\hline \multicolumn{5}{|l|}{ Systolic blood pressure, mmHg } \\
\hline Mean \pm SD & $123.0 \pm 26.4$ & $117.8 \pm 25.7$ & $123.6 \pm 26.4$ & 0.003 \\
\hline Range & $50-250$ & 50-197 & $50-250$ & \\
\hline \multicolumn{5}{|l|}{ Diastolic blood pressure, $\mathrm{mmHg}$} \\
\hline Mean \pm SD & $69.3 \pm 15.0$ & $68.0 \pm 15.6$ & $69.5 \pm 15.0$ & 0.1153 \\
\hline Range & 21-150 & $30-110$ & 21-150 & \\
\hline \multicolumn{5}{|l|}{ Pulse rate, beats/min } \\
\hline Mean \pm SD & $92.7 \pm 20.5$ & $96.2 \pm 19.5$ & $92.3 \pm 20.6$ & 0.0016 \\
\hline Range & $30-180$ & $44-142$ & $30-180$ & \\
\hline \multicolumn{5}{|l|}{ Rectal examination } \\
\hline Bright red blood & $89(4.4) ; 3.5-5.3$ & $14(6.5) ; 3.2-9.8$ & 75 (4.2); 3.2-5.1 & 0.1115 \\
\hline Melena & 456 (22.6); 20.8-24.4 & 43 (20.0); 14.6-25.4 & 413 (22.9); 20.9-24.8 & 0.3345 \\
\hline No bleeding & 248 (12.3); 10.8-13.7 & $23(10.7) ; 6.5-14.9$ & 225 (12.5); 10.9-14.0 & 0.4553 \\
\hline Not recorded & 851 (42.1); 40.0-44.3 & 109 (50.7); 44.0-57.4 & 742 (41.1); 38.8-43.4 & 0.0071 \\
\hline Occult blood positive & 376 (18.6); 16.9-20.3 & $26(12.1) ; 7.7-16.5$ & $350(19.4) ; 17.6-21.2$ & 0.0094 \\
\hline \multicolumn{5}{|l|}{ Nasogastric tube aspirate } \\
\hline Bile & $18(0.9) ; 0.5-1.3$ & - & 18 (1.0); 0.5-1.5 & 0.1413 \\
\hline Bright red blood & 123(6.1);5.1-7.1 & $16(7.4) ; 3.9-11.0$ & $107(5.9) ; 4.8-7.0$ & 0.03802 \\
\hline Coffee ground material & $172(8.5) ; 7.3-9.7$ & $10(4.7) ; 1.8-7.5$ & 162 (9.0); 7.7-10.3 & 0.0318 \\
\hline No findings & $135(6.7) ; 5.6-7.8$ & $12(5.6) ; 2.5-8.7$ & $123(6.8) ; 5.7-8.0$ & 0.4938 \\
\hline Not recorded & 1572 (77.8); 76.0-79.6 & 177 (82.3); 77.2-87.5 & 1394 (77.3); 75.4-79.2 & 0.0926 \\
\hline \multicolumn{5}{|l|}{ Documented } \\
\hline Initial hemodynamic instability & $630(31.2) ; 29.2-33.2$ & 67 (31.2); 24.9-37.4 & 563 (31.2); 29.1-33.3 & 0.9932 \\
\hline Abdominal tenderness & 554 (27.4); 27.4-29.4 & 62 (28.8); 22.7-34.9 & 492 (27.3); 25.2-29.3 & 0.6236 \\
\hline Hepatomegaly & $136(6.7) ; 5.6-7.8$ & $51(23.7) ; 18.0-29.5$ & $85(4.7) ; 3.7-5.7$ & $<0.0001$ \\
\hline Splenomegaly & $73(3.6) ; 2.8-4.4$ & 38 (17.7); 12.5-22.8 & 35 (1.9); 1.3-2.6 & $<0.0001$ \\
\hline Edema & 190 (9.4); 8.1-10.7 & 49 (22.8); 17.1-28.4 & 141 (7.8); 6.6-9.1 & $<0.0001$ \\
\hline \multicolumn{5}{|l|}{ Ascites } \\
\hline None & 1861 (92.1); 91.0-93.3 & 132 (61.4); 54.8-68.0 & 1729 (95.8); 94.9-96.7 & $<0.0001$ \\
\hline Mild-moderate & 127 (6.3); 5.2-7.4 & 61 (28.4); 22.3-34.4 & $66(3.7) ; 2.8-4.5$ & $<0.0001$ \\
\hline Severe & $32(1.6) ; 1.0-2.1$ & 22 (10.2); 6.2-14.3 & $10(0.6) ; 0.2-0.9$ & $<0.0001$ \\
\hline \multicolumn{5}{|l|}{ Hepatic encephalopathy } \\
\hline None & 1968 (97.4); 96.7-98.1 & 181 (84.2); 79.3-89.1 & 1787 (99.0); 98.5-99.5 & $<0.0001$ \\
\hline Mild-moderate & 42 (2.1); 1.5-2.7 & 27 (12.6); 8.1-17.0 & $15(0.8) ; 0.4-1.3$ & $<0.0001$ \\
\hline Severe & $10(0.5) ; 0.2-0.8$ & 7 (3.3); 0.9-5.7 & $3(0.2) ; 0.0-0.4$ & $<0.0001$ \\
\hline Jaundice & $91(4.5) ; 3.6-5.4$ & 47 (21.9); 16.3-27.4 & $44(2.4) ; 1.7-3.2$ & $<0.0001$ \\
\hline
\end{tabular}

Data presented as n (\%); 95\% Cl unless otherwise indicated. ASA American Society of Anesthesiologists score

presentation of hematochezia (OR 3.02 [95\% CI 1.46 to 6.22$]$ ), hematemesis, (OR 2.65 [95\% CI 1.61 to 4.36$]$ ) or stigmata of chronic liver disease (OR 2.49 [95\% CI 1.46 to 4.25]). These findings include all criteria identified in the study by Pongprasobchai et al (8). The additional variables of excessive alcohol consumption, antiplatelet agents and hematochezia may relate to some of the aforementioned differences.
When simple laboratory test values, which can be obtained in a relatively short period from the time a patients presents with UGIB, were included in the multivariable model, they did not have an effect on the predictive probability of the model, but the study may have been underpowered in the analysis of these variables. Of note, the Thai study by Pongprasobchai et al (8) also did not find any predictive value attributable to laboratory data. 
TABLE 3

Baseline laboratory data on initial bleeding event for patients with either nonvariceal upper gastrointestinal bleeding or variceal bleeding

\begin{tabular}{|c|c|c|c|}
\hline \multirow[b]{2}{*}{ Variable } & \multicolumn{2}{|c|}{ Bleed } & \multirow[b]{2}{*}{$\mathbf{P}$} \\
\hline & Variceal & Nonvariceal & \\
\hline Hemoglobin, g/L & $93.8 \pm 23.2$ & $98.5 \pm 28.2$ & 0.0474 \\
\hline Hematocrit & $0.28 \pm 0.07$ & $0.29 \pm 0.08$ & 0.0277 \\
\hline Platelet cell count, $\times 10^{9} / \mathrm{L}$ & $143.5 \pm 87.8$ & $261.6 \pm 123.8$ & $<0.0001$ \\
\hline Blood urea nitrogen, mmol/L & $10.9 \pm 8.4$ & $13.8 \pm 10.3$ & $<0.0001$ \\
\hline Alanine aminotransferase, U/L & $68.7 \pm 198.5$ & $34.3 \pm 87.9$ & $<0.0001$ \\
\hline Aspartate aminotransferase, U/L & $125.9 \pm 421.6$ & $46.9 \pm 134.2$ & $<0.0001$ \\
\hline Alkaline phosphatase, U/L & $139.7 \pm 120.1$ & $97.8 \pm 104.7$ & $<0.0001$ \\
\hline Gamma-glutamyltransferase, U/L & $157.0 \pm 190.6$ & $97.7 \pm 219.5$ & $<0.0001$ \\
\hline Total bilirubin, $\mu \mathrm{mol} / \mathrm{L}$ & $44.1 \pm 54.6$ & $17.8 \pm 38.4$ & $<0.0001$ \\
\hline Serum albumin, g/L & $27.1 \pm 6.72$ & $30.2 \pm 7.41$ & $<0.0001$ \\
\hline International normalized ratio & $\begin{array}{c}1.6 \pm 0.6 \\
\text { (Median 1.40) }\end{array}$ & $\begin{array}{c}1.6 \pm 1.6 \\
\text { (Median 1.15) }\end{array}$ & $<0.0001$ \\
\hline Creatinine, $\mu \mathrm{mol} / \mathrm{L}$ & $108.8 \pm 104.7$ & $121.8 \pm 103.9$ & 0.0014 \\
\hline
\end{tabular}

Data presented as mean \pm SD unless otherwise indicated

\section{TABLE 4}

Historical and clinical variables predictive of a variceal cause for upper gastrointestinal bleeding on multivariable analysis

\begin{tabular}{lc}
\hline Variable & $\begin{array}{c}\text { Multivariable analysis } \\
\text { OR (95\% CI) }\end{array}$ \\
\hline Documented history of liver disease & $6.36(3.59-11.3)$ \\
Documented history of excess alcohol use & $2.28(1.37-3.77)$ \\
Presenting with hematochezia & $3.02(1.46-6.22)$ \\
Presenting with hematemesis & $2.65(1.61-4.36)$ \\
Use of antithrombotics & $0.44(0.35-0.78)$ \\
Stigmata of chronic liver disease* & $2.49(1.46-4.25)$ \\
\hline
\end{tabular}

*Stigmata of chronic liver disease is a composite of the presence of hepatomegaly, splenomegaly, peripheral edema, jaundice, hepatic encephalopathy and ascites

To highlight the clinical impact of our findings, using our logistic regression model, we calculated the post-test predicted probabilities of a patient bleeding from a variceal source based on different possible clinical scenarios. From a baseline pretest (ie, prevalence) probability of $10.6 \%$, use of antithrombotics in the absence of all other factors, dropped the predicted probability of a variceal source to $0 \%$. In the case of a patient with a history of chronic liver disease and noted stigmata of chronic liver disease (the two most commonly used predictors in clinical settings), the predicted probability of a variceal source increased to $46 \%$. If all significant predictors are present in a given patient, the predicted probability of a variceal source increases to $94 \%$ (Table 5). Such differences in predicted probabilities may be useful in refining a tailored management approach including determining the urgent need for an intravenous proton pump inhibitor or octreotide, or that of an endoscopy within $12 \mathrm{~h}$ versus $24 \mathrm{~h}$. Additional research is needed to explore such implications.

The results of our study suggest that simple bedside parameters can be useful in the prediction of a variceal source among patients who present with UGIB. Significant variables include a history of liver disease, excessive alcohol use and the absence of antithrombotic medication use, as well as findings on physical examination of hematemesis, hematochezia and stigmata of chronic liver disease. The clinical implications of these findings warrant additional evaluative research in this patient population at high risk of negative outcomes.
TABLE 5

Calculated predicted probabilities* of a patient bleeding from a variceal source based on different possible clinical scenarios

\begin{tabular}{lccc}
\hline & \multicolumn{3}{c}{ Scenario } \\
\cline { 2 - 4 } Variable & $\mathbf{1}$ & $\mathbf{2}$ & $\mathbf{3}$ \\
\hline History of liver disease & - & + & + \\
History of excessive alcohol use & - & - & + \\
Hematemesis & - & - & + \\
Hematochezia & - & - & + \\
Antithrombotics & + & - & - \\
Stigmata of chronic liver disease & - & + & + \\
Predicted variceal bleeding, \% & 1 & 22 & 83 \\
\hline
\end{tabular}

${ }^{*}$ Calculated for a baseline prevalence of variceal bleeding of $10.6 \%$. - Negative; + Positive

FINANCIAL SUPPORT: The REASON study was funded by an atarms-length grant from Astra Zeneca Canada Inc.

DISCLOSURES: Alan Barkun is a consultant for AstraZeneca, Takeda Canada, Boston Scientific Inc, and Olympus Canada. Ahmad Alharbi, Majid Almadi and Myriam Martel report no conflicts of interest.

\section{Appendix 1}

Primary investigators of participating hospitals in the national REgistry of patients undergoing endoscopic and/ or Acid Suppression therapy and Outcomes analysis for upper gastrointestinal bleediNg (REASON)

\begin{tabular}{|c|c|}
\hline Principal investigator & Address \\
\hline \multirow[t]{4}{*}{ Dr David Armstrong } & McMaster University Health Science Centre \\
\hline & HSC 4W8, Gastroenterology \\
\hline & 1200 Main Street West \\
\hline & Hamilton, Ontario L8S 4J9 \\
\hline \multirow[t]{3}{*}{ Dr Alan Barkun } & Hôpital General de Montreal \\
\hline & Room D7148 GI 1650 Cedar Avenue \\
\hline & Montreal, Quebec H3G 1A4 \\
\hline \multirow[t]{3}{*}{ Dr Raymond Bourdages } & Hotel Dieu de Levis \\
\hline & 143 Wolfe Street \\
\hline & Levis, Quebec G6V $3 Z 1$ \\
\hline \multirow[t]{4}{*}{ Dr Marc Bradette } & Hotel-Dieu de Quebec \\
\hline & 7th Floor Gastroenterology \\
\hline & 11 Cote du Palais \\
\hline & Quebec, Quebec G1R $2 J 6$ \\
\hline \multirow[t]{4}{*}{ Dr Ford Bursey } & The Health Science Centre \\
\hline & GI Unit/OPD Clinic \\
\hline & 300 Prince Phillip Drive \\
\hline & St John's, Newfoundland A1B 3V6 \\
\hline \multirow[t]{3}{*}{ Dr Naoki Chiba } & Surrey GI Research \\
\hline & $105-21$ Surrey Street \\
\hline & Guelph, Ontario N1H 3R3 \\
\hline \multirow[t]{3}{*}{ Dr Alan Cockeram } & Hillyard Place Building \\
\hline & 270-560 Main Street \\
\hline & Saint John, New Brunswick E2K 1J5 \\
\hline \multirow[t]{2}{*}{ Dr Gilbert Doummar } & 1000-1660 Ch du Tremblay \\
\hline & Longueuil, Quebec J4N 1E1 \\
\hline \multirow[t]{4}{*}{ Dr Carlo Fallone } & 687 des Pins Avenue, WR228 \\
\hline & Gastroenterology Division \\
\hline & $\begin{array}{l}\text { McGill University Health Centre - Royal Victoria } \\
\text { Hospital }\end{array}$ \\
\hline & Montreal, Quebec H3A 1A1 \\
\hline
\end{tabular}

Continued on next page 


\begin{tabular}{|c|c|}
\hline \multicolumn{2}{|l|}{ Appendix 1 - CONTINUED } \\
\hline Principal investigator & Address \\
\hline \multirow[t]{3}{*}{ Dr James Gregor } & 375 South Street, Room N552 375 \\
\hline & PO Box 5375 Station B \\
\hline & London, Ontario N6A 4G5 \\
\hline \multirow[t]{3}{*}{ Dr Robert Hilsden } & Health Science Centre - Faculty of Medicine \\
\hline & 3330 Hospital Drive Northwest \\
\hline & Calgary, Alberta T2N 4N1 \\
\hline \multirow[t]{3}{*}{ Dr Gilles Jobin } & Hopital Maisonneuve - Rosemont Polyclinique \\
\hline & Porte 205295 - 5415 de L'Assomption Blvd \\
\hline & Montreal, Quebec H1T 2M4 \\
\hline \multirow[t]{3}{*}{ Dr Raymond Lahaie } & CHUM-Hopital Saint-Luc \\
\hline & 1058 rue Saint-Denis \\
\hline & Montreal, Quebec H2X $3 \mathrm{~J} 4$ \\
\hline \multirow[t]{3}{*}{ Dr Gaetano Morelli } & Immeuble Commercial \\
\hline & $300-245$ Victoria Avenue \\
\hline & Westmount, Quebec H3Z 2M6 \\
\hline \multirow[t]{3}{*}{ Dr Pardeep Nijhawan } & Business Building \\
\hline & 330 Highway 7 East \\
\hline & Richmond Hill, Ontario L4B 3P8 \\
\hline \multirow[t]{3}{*}{ Dr Kenneth Render } & Gastroenterology and Hepatology \\
\hline & 564 Leon Avenue \\
\hline & Kelowna, British Columbia V1Y 6J6 \\
\hline \multirow[t]{3}{*}{ Dr Alaa Rostom } & Ottawa Civic Hospital \\
\hline & Room A163, 1053 Carling Avenue \\
\hline & Ottawa, Ontario K1Y 4E9 \\
\hline \multirow[t]{4}{*}{ Dr Gurpal Sandha } & Zeidler Ledcor Centre \\
\hline & GILDR Group \\
\hline & 130 University Campus \\
\hline & Edmonton, Alberta T6G 2X8 \\
\hline \multirow[t]{3}{*}{ Dr Thomas Sylwestrowicz } & St Paul Hospital \\
\hline & 1702-20th Street West \\
\hline & Saskatoon, Saskatchewan S7M 0Z9 \\
\hline \multirow{4}{*}{$\begin{array}{l}\text { Dr Sander Veldhuyzen } \\
\text { van Zanten }\end{array}$} & Victoria General Hospital \\
\hline & QEII HSC Victoria General Site \\
\hline & $\begin{array}{l}\text { Rm } 927 \text { - Centennial Wing 9th Floor } \\
\text { Gastroenterology }\end{array}$ \\
\hline & 278 Tower Road, Halifax, Nova Scotia B3H 3 Y9 \\
\hline \multirow[t]{4}{*}{ Dr Lawrence Worobetz } & Royal University Hospital \\
\hline & University of Saskatchewan \\
\hline & 103 Hospital Drive, \\
\hline & Saskatoon, Saskatchewan S7N 0W8 \\
\hline
\end{tabular}

\section{REFERENCES}

1. Carbonell N, Pauwels A, Serfaty L, Fourdan O, Levy VG, Poupon R. Improved survival after variceal bleeding in patients with cirrhosis over the past two decades. Hepatology 2004;40:652-9.

2. Graham DY, Smith JL. The course of patients after variceal hemorrhage. Gastroenterology 1981;80:800-9.

3. Chalasani N, Kahi C, Francois F, et al. Improved patient survival after acute variceal bleeding: A multicenter, cohort study. Am J Gastroenterol 2003;98:653-9.

4. Garcia-Tsao G, Bosch J, Groszmann RJ. Portal hypertension and variceal bleeding - unresolved issues. Summary of an American Association for the study of liver diseases and European Association for the study of the liver single-topic conference. Hepatology 2008;47:1764-72.

5. Garcia-Tsao G, Sanyal AJ, Grace ND, Carey W. Prevention and management of gastroesophageal varices and variceal hemorrhage in cirrhosis. Hepatology 2007;46:922-38

6. Villanueva C, Piqueras M, Aracil C, et al. A randomized controlled trial comparing ligation and sclerotherapy as emergency endoscopic treatment added to somatostatin in acute variceal bleeding. J Hepatol 2006;45:560-7.

7. Banares R, Albillos A, Rincon D, et al. Endoscopic treatment versus endoscopic plus pharmacologic treatment for acute variceal bleeding: A meta-analysis. Hepatology 2002;35:609-15.

8. Pongprasobchai S, Nimitvilai S, Chasawat J, Manatsathit S. Upper gastrointestinal bleeding etiology score for predicting variceal and non-variceal bleeding. World J Gastroenterol 2009;15:1099-104.

9. Barkun A, Sabbah S, Enns R, et al. The Canadian Registry on Nonvariceal Upper Gastrointestinal Bleeding and Endoscopy (RUGBE): Endoscopic hemostasis and proton pump inhibition are associated with improved outcomes in a real-life setting. Am J Gastroenterol 2004;99:1238-46.

10. Al Sibae MR, Cappell MS. Accuracy of MELD scores in predicting mortality in decompensated cirrhosis from variceal bleeding, hepatorenal syndrome, alcoholic hepatitis, or acute liver failure as well as mortality after non-transplant surgery or TIPS. Dig Dis Sci 2011;56:977-87.

11. Barkun AN, Bardou M, Kuipers EJ, et al. International consensus recommendations on the management of patients with nonvariceal upper gastrointestinal bleeding. Ann Intern Med 2010;152:101-13.

12. Garcia-Tsao G, Bosch J. Management of varices and variceal hemorrhage in cirrhosis. N Engl J Med 2010;362:823-32.

13. Kravetz D, Sikuler E, Groszmann RJ. Splanchnic and systemic hemodynamics in portal hypertensive rats during hemorrhage and blood volume restitution. Gastroenterology 1986;90:1232-40.

14. Castaneda B, Morales J, Lionetti R, et al. Effects of blood volume restitution following a portal hypertensive-related bleeding in anesthetized cirrhotic rats. Hepatology 2001;33:821-5. 


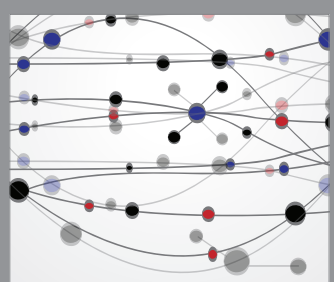

The Scientific World Journal
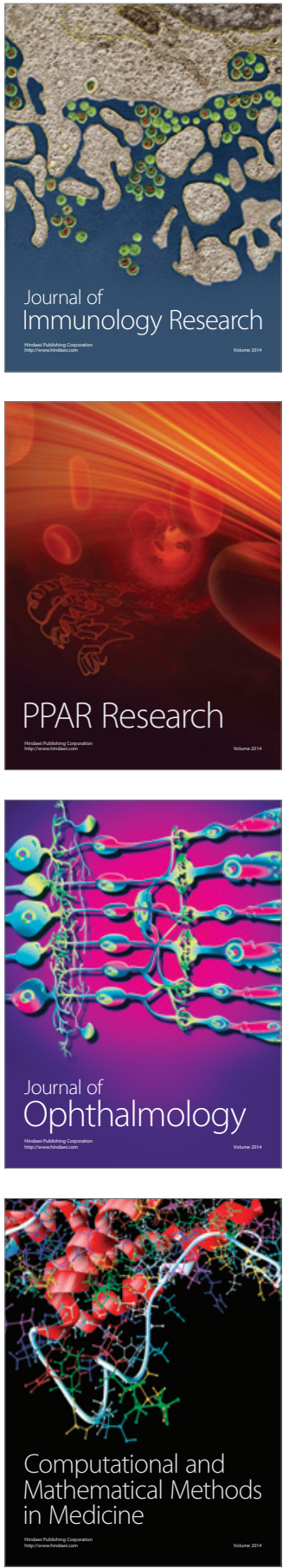

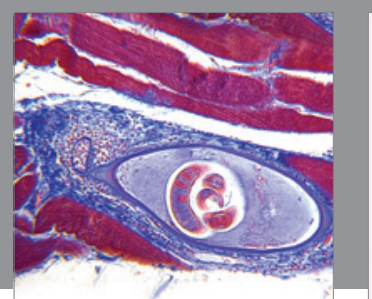

Gastroenterology Research and Practice

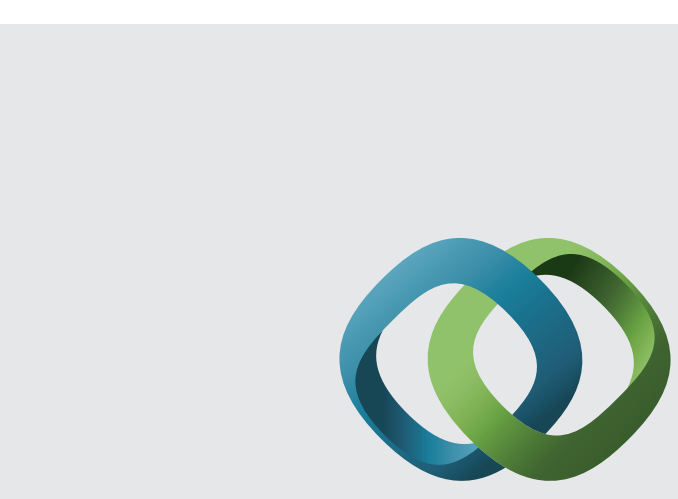

\section{Hindawi}

Submit your manuscripts at

http://www.hindawi.com
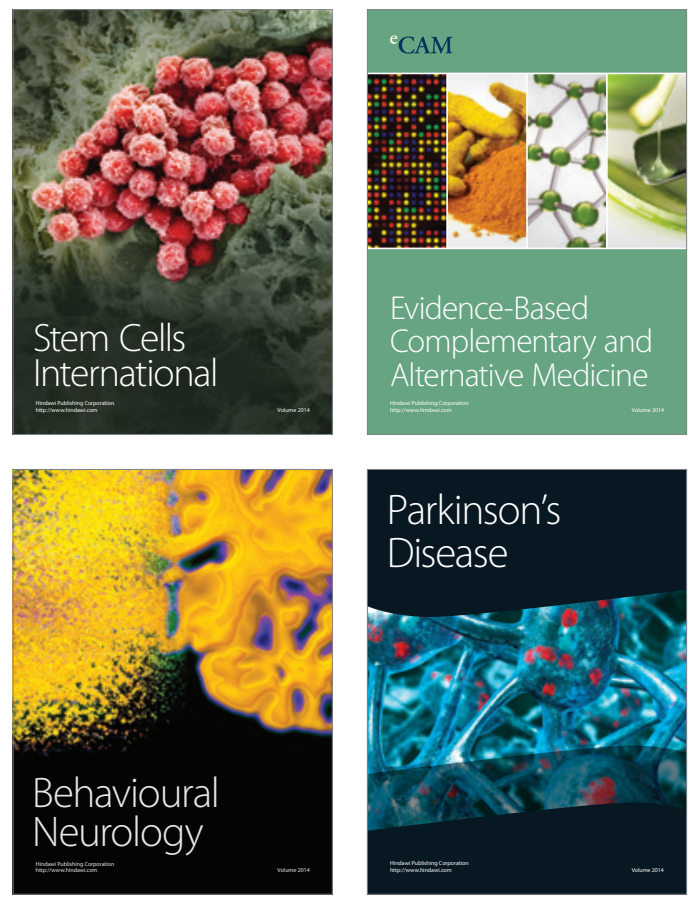
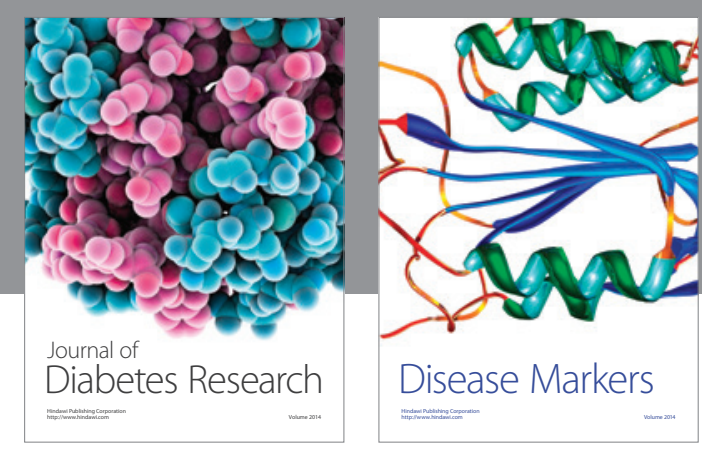

Disease Markers
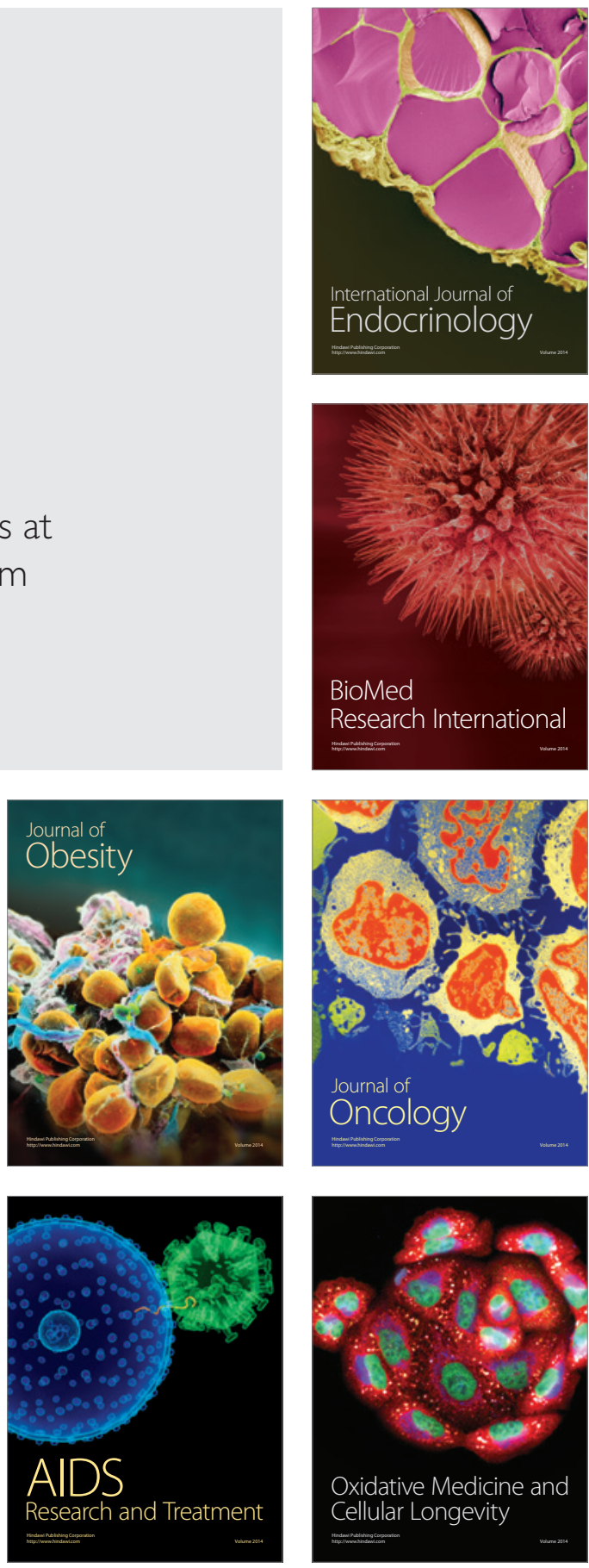